\title{
ASUPAN ENERGI BERHUBUNGAN DENGAN KEJADIAN DIABETES MELLITUS PADA PASIEN LANSIA RAWAT JALAN RSUD Dr. SAIFUL ANWAR (ENERGY INTAKE IS RELATED TO DIABETES MELLITUS IN ELDERLY OUTPATIENTS AT RSUD Dr. SAIFUL ANWAR) Winny Dhestina ${ }^{1}$, Rakhmawati Widya Safitri ${ }^{2}$, Anggun Rindang Cempaka ${ }^{3}$, Adhe Hariani Ciptaningsih ${ }^{4}$ \\ ${ }^{1,2,3)}$ Fakultas Kedokteran Universitas Brawijaya, ${ }^{4}$ Instalasi Gizi RSUD Dr. Saiful Anwar \\ Email: windhestina@gmail.com
}

\begin{abstract}
Result of National Basic Health 2018 showed that the prevalence of Diabetes Mellitus increased from 6,9\% on 2013 to $8,5 \%$ on 2018. Factors affecting DM are energy intake and nutritional status. The objective of this study was to know the association between energy intake and other factors with incidence of Diabetes Mellitus (DM) in elderly patients RSUD Dr. Saiful Anwar Malang. Method of this study was cross-sectional. Sampling technique was non probability sampling by purposive sampling with total number of samples were 35. Result of this study showed that energy intake was significantly associated with incidence of $D M(p=0,046)$. Fat, carbohydrates, fiber, cholesterol and saturated fatty acid (SFA) was not significantly associated with incidence of $D M(p>0,05)$. There was no significantly difference between nutritional status (underweight and normal, with overweight and obese) with incidence of DM $(p>0,05)$. In conclusion, energy intake was associated with incidence of DM in elderly patients RSUD Dr. Saiful Anwar Malang.
\end{abstract}

Keyword: energy intake; diabetes mellitus; elderly patients

Abstrak: Hasil Riset Kesehatan Dasar pada tahun 2018 didapatkan peningkatan prevalensi Diabetes Mellitus (DM) dari 6,9\% pada tahun 2013 menjadi 8,5\% pada tahun 2018. Faktor yang dapat mempengaruhi kejadian DM diantaranya adalah asupan energi dan status gizi. Penelitian ini bertujuan untuk mengetahui hubungan asupan energi dengan kejadian DM pada pasien lansia rawat jalan di RSUD Dr. Saiful Anwar Malang. Metode penelitian adalah cross-sectional. Teknik sampling dilakukan dengan non-probability sampling secara purposive sampling dan diperoleh sampel sebanyak 35 orang. Hasil peneltian didapatkan bahwa terdapat hubungan yang signifikan antara asupan energi dengan kejadian DM $(p=0,046)$. Tidak terdapat hubungan yang signifikan antara asupan lemak, karbohidrat, serat, kolesterol dan saturated fatty acid (SFA) dengan kejadian DM $(p>0,05)$. Tidak terdapat perbedaan antara status gizi (underweight dan normal, dengan overweight dan obesitas) dengan kejadian DM ( $p>0.05$ ). Maka dapat disimpulkan bahwa asupan energi mempengaruhi kejadian DM pada pasien lansia rawat jalan di RSUD Dr. Saiful Anwar

Kata Kunci: asupan energi; diabetes mellitus; pasien lansia

Copyright (C) 2020 Jurnal Skala Kesehatan. Politeknik Kesehatan Banjarmasin All rights reserved

Corresponding Author:

Winny Dhestina,

Fakultas Kedokteran Universitas Brawijaya

Email : windhestina@gmail.com 


\section{PENDAHULUAN}

Diabetes Mellitus (DM) adalah penyakit kronis yang terjadi ketika pankreas tidak memproduksi insulin dalam jumlah yang cukup atau ketika tubuh tidak dapat menggunakan insulin secara efektif. Insulin adalah hormon yang mengatur kadar gula darah. Hiperglikemia atau kenaikan kadar gula darah adalah gejala umum dari DM yang tidak terkontrol, yang dapat menyebabkan kerusakan sistem tubuh [1].

Di dunia pada tahun 2014 terdapat sekitar 422 juta penderita diabetes yang berusia di atas 18 tahun, dengan prevalensi 8,5\%. Wilayah Asia Tenggara adalah wilayah dengan jumlah penderita diabetes tertinggi kedua di dunia, yaitu sebesar 96 juta orang, dengan prevalensi 8,6\% [2]. Hasil Riset Kesehatan Dasar pada penduduk umur $\geq 15$ tahun di Indonesia menunjukkan adanya peningkatan prevalensi Diabetes Mellitus menurut konsensus Perkeni 2011 dari 6,9\% pada tahun 2013 menjadi 8,5\% pada tahun 2018 [3].

Diabetes dapat menyebabkan berbagai komplikasi seperti stroke, gangguan penglihatan, serangan jantung, gagal ginjal, amputasi, serta meningkatkan risiko kematian premature [2]. Pada tahun 2015, diabetes merupakan penyebab kematian terbesar kedelapan di dunia, yaitu sekitar 1,6 juta [1]. Data WHO menunjukkan persentase kematian yang disebabkan karena diabetes paling banyak terjadi pada kelompok lansia, dari kelompok umur 60-69 tahun, 50-59 tahun, dan 70-79 tahun [2]. Di Indonesia, penderita diabetes juga paling banyak ditemukan pada pasien lansia, dari kelompok umur 55-64 tahun sebesar 6,3\% dan 65-74 tahun sebesar 6\% [3]. Pada populasi lansia, 1 dari 4 orang berusia di atas 65 tahun mengalami Diabetes Mellitus Tipe 2, dan 50\% lainnya mengalami prediabetes, yang menyebabkan risiko mendapatkan diabetes pada usia di atas 75 tahun [4].

Faktor risiko diabetes merupakan gabungan faktor genetik dan gaya hidup [5]. Etnis, riwayat diabetes dalam keluarga, dan diabetes gestasional, digabungkan dengan usia lanjut, berat badan lebih dan obesitas, pola makan yang tidak sehat, aktivitas fisik yang kurang, dan perilaku merokok meningkatkan risikonya [2]. Orang yang obes dan memiliki pola makan yang tidak seimbang (terutama karbohidrat dan lemak) memiliki kemungkinan lebih tinggi untuk terkena DM [5]. Faktor yang dapat diubah (modifiable) yang dapat meningkatkan risiko DM adalah obesitas [6]. Penelitian lain di Xi'an, Cina menunjukkan adanya hubungan positif antara usia lanjut, indeks massa tubuh yang tinggi, pola makan yang tidak sehat dengan risiko DM [7]. Pola makan yang tidak sehat (tinggi konsumsi daging olahan, minuman manis, dan rendah serat) menunjukkan bukti yang kuat dalam peningkatan risiko DM [8]. Penelitian pada petani dan buruh di Semarang juga menunjukkan adanya hubungan yang signifikan antara IMT dan asupan energi dengan kejadian diabetes [9].

Pola makan yang tidak sehat tergambar dari jumlah asupannya, baik itu energi, karbohidrat, dan lemak. Asupan energi yang berlebih dalam waktu yang lama menyebabkan terjadinya penumpukan lemak yang berlebih di dalam tubuh. Lemak tubuh yang berlebih sebagai akibat dari pola makan dan aktivitas fisik adalah faktor risiko terkuat dari diabetes [2]. Selain itu, pemilihan jenis karbohidrat dan lemak juga menentukan sehat atau tidaknya pola makan. Asupan serat berperan dalam meningkatkan waktu transit makanan di lambung yang dapat memperlambat penyerapan gula di usus halus. Penelltian pada pasien diabetes di RSUD Dr Kariadi Semarang menunjukkan adanya hubungan yang bermakna antara kadar gula darah 
puasa dengan asupan energi, karbohidrat, dan serat, serta antara kadar gula darah 2 jam pp dengan asupan energi dan serat [10]. Berdasarkan uraian tersebut, penelitian ini bertujuan untuk meneliti hubungan antara asupan energi, karbohidrat, serat, lemak, kolesterol, saturated fatty acid (SFA), dan status gizi dengan kejadian Diabetes Mellitus Tipe 2 pada pasien lansia di Poliklinik RSUD Dr Saiful Anwar Malang.

\section{BAHAN DAN METODE}

Jenis penelitian mengggunakan metode cross-sectional. Penelitian dilaksanakan di Poli Gizi Rumah Sakit Dr. Saiful Anwar Malang yang dilaksanakan pada bulan Mei 2019. Variabel terdisi dari variabel independen yaitu asupan energi, lemak, karbohidrat, serat, kolesterol, SFA, status gizi, dan variabel dependen yaitu kejadian DM. Penelitian ini telah mendapatkan persetujuan dari komite etik penelitian RSUD Dr. Saiful Anwar Malang no. 400/079/K.3/302/2019. Sumber data diperoleh dari data primer dan data sekunder. Data primer didapat melalui wawancara yaitu usia, jenis kelamin, serta data asupan dengan metode Semi-Quantitative Food Frequency Questionnaire (SQ-FFQ) dan alat bantu berupa food model. Sedangkan data sekunder berupa diagnosis medis. Subjek penelitian diambil dengan menggunakan teknik non probabilty sampling secara purposive sampling dan diperoleh sampel sebanyak 35 orang. Kriteria inklusi penelitian ini adalah pasien dengan usia diatas 50 tahun. Penelitian ini menggunakan analisis univariat dan bivariat. Analisis univariat disajikan dalam tabel frekuensi meliputi jenis kelamin, umur, status gizi dan diagnosis medis. Analisis bivariat menggunakan software SPSS 16.0 dan disajikan dalam tabel silang untuk mengetahui hubungan asupan zat gizi dengan kejadian DM melalui uji Chi Square. Untuk mengetahui perbedaan status gizi dengan kejadian DM dilakukan dengan uji One Way Annova. 


\section{HASIL DAN PEMBAHASAN}

\section{a. Karakteristik Responden}

Data karakteristik responden yang diperoleh adalah diagnosis medis, jenis kelamin, dan usia melalui wawancara dan rekam medis. Data status gizi diperoleh dengan melakukan pengukuran antropometri berat badan dan tinggi badan.

\begin{tabular}{|c|c|c|}
\hline Karakteristik & $\mathbf{N}$ & $\%$ \\
\hline \multicolumn{3}{|l|}{ Diagnosis } \\
\hline a. DM & 20 & 57,1 \\
\hline b. Non DM & 15 & 42,9 \\
\hline \multicolumn{3}{|l|}{ Jenis Kelamin } \\
\hline b. Perempuan & 21 & 60 \\
\hline \multicolumn{3}{|l|}{ Kategori Usia } \\
\hline a. $50-64$ & 23 & 65,7 \\
\hline b. $65-80$ & 10 & 28,6 \\
\hline c. $>80$ & 2 & 5,7 \\
\hline \multicolumn{3}{|l|}{ Status Gizi } \\
\hline a. Kurang & 2 & 5,7 \\
\hline b. Normal & 6 & 17,1 \\
\hline c. Overweight & 12 & 34,3 \\
\hline d. Obesitas & 15 & 42,9 \\
\hline
\end{tabular}

Tabel 1 menunjukkan bahwa responden dengan diagnosis DM sebanyak 20 orang $(57,1 \%)$ sedangkan responden yang tidak terdiagnosis DM sebanyak 15 orang $(42,9 \%)$. Berdasarkan jenis kelamin, jumlah responden berjenis kelamin laki-laki sebanyak 14 orang $(40 \%)$ sedangkan responden berjenis kelamin perempuan sebanyak 21 orang $(60 \%)$. Berdasarkan kategori usia, responden yang berusia 50-64 tahun sebanyak 23 orang $(65,7 \%)$, usia $65-80$ tahun sebanyak 10 orang $(28,6 \%)$, usia $>80$ tahun sebanyak 2 orang $(5,7 \%)$. Berdasarkan status gizi, sebanyak 2 orang $(2,7 \%)$ tergolong gizi kurang, 6 orang $(17,1 \%)$ tergolong gizi normal, 12 orang $(34,3 \%)$ tergolong overweight, dan 15 orang $(42,9 \%)$ tergolong obesitas. 


\section{b. Asupan Energi dengan Kejadian DM}

Data asupan energi responden diperoleh dari hasil SQ-FFQ. Berikut adalah hasil analisis hubungan asupan energi dengan kejadian DM melalui uji Chi Square pada SPSS.

Tabel 2. Hubungan Asupan Energi dengan Kejadian DM

\begin{tabular}{ccccc}
\hline Kategori & \multicolumn{2}{c}{ Kejadian DM } & Jumlah & $\boldsymbol{P}$ Value \\
\cline { 2 - 5 } asupan & Non DM & DM & & \\
\hline Baik & 12 & 9 & 21 & \\
Lebih & 3 & 11 & 14 & 0,046 \\
Total & 15 & 20 & 35 & \\
\hline
\end{tabular}

Tabel 2 menunjukkan bahwa asupan energi dengan kategori baik pada responden DM sebanyak 9 orang sedangkan responden Non DM sebanyak 12 orang. Asupan energi dengan kategori lebih pada responden DM sebanyak 11 orang sedangkan responden Non DM sebanyak 3 orang. Berdasarkan uji statistik nilai $p$ adalah 0,046 maka dari itu dapat disimpulkan bahwa terdapat perbedaan asupan energi responden dengan kejadian DM. Hasil ini sejalan dengan penelitian yang menunjukkan ketidakseimbangan energi sekitar 50-100 kkal per hari dapat berkontribusi pada peningkatan berat badan bertahap [5]. Penelitian lain yang melakukan intervensi gaya hidup dengan restriksi kalori dan olahraga untuk penurunan berat badan menunjukkan hasil yang secara signifikan dapat menurunkan kejadian diabetes pada pasien berisiko tinggi dengan gangguan toleransi glukosa sebesar 58\% [11]. Konsumsi energi yang berlebih berdampak pada jumlah glukosa dalam tubuh. Jika hal ini terjadi dalam waktu yang lama dapat mengakibatkan penurunan fungsi sel beta pankreas sehingga terjadi defisiensi dan resistensi insulin. Hal ini menyebabkan gula darah tidak dapat disimpan dan digunakan sehingga menumpuk di dalam darah. Akibatnya, kadar gula darah meningkat, hingga tubuh tidak mampu menyimpan maupun menggunakannya, hingga menyebabkan diabetes [9]. 


\section{c. Asupan Lemak, Kolesterol dan SFA dengan Kejadian DM}

Data asupan lemak, kolesterol dan SFA responden diperoleh dari hasil SQFFQ. Berikut adalah hasil analisis hubungan asupan lemak, kolesterol dan SFA dengan kejadian DM melalui uji Chi Square pada SPSS.

Tabel 3 Hubungan Asupan Lemak, Kolesterol dan SFA dengan Kejadian DM

\begin{tabular}{cccccc}
\hline \multirow{2}{*}{ Zat gizi } & Kategori & \multicolumn{2}{c}{ Kejadian DM } & \multirow{2}{*}{ Jumlah } & \multirow{2}{*}{$\boldsymbol{P}$ Value } \\
\cline { 3 - 5 } asupan & Non DM & DM & & \\
\hline \multirow{3}{*}{ Lemak } & Baik & 8 & 10 & 18 & \\
& Lebih & 7 & 10 & 17 & 1 \\
& Total & 15 & 20 & 35 & \\
\multirow{3}{*}{ Kolesterol } & Normal & 12 & 16 & 28 & \\
& Berlebih & 3 & 4 & 7 & 1 \\
& Total & 15 & 20 & 35 & \\
\multirow{2}{*}{ SFA } & Normal & 1 & 2 & 3 & \\
& Berlebih & 14 & 18 & 32 & 1 \\
& Total & 15 & 20 & 35 & \\
\hline
\end{tabular}

Tabel 3 menunjukkan bahwa asupan lemak dengan kategori baik pada responden DM sebanyak 10 orang sedangkan responden Non DM sebanyak 8 orang. Asupan lemak dengan kategori lebih pada responden DM sebanyak 10 orang sedangkan responden Non DM sebanyak 7 orang. Berdasarkan uji statistik nilai $p$ adalah 1 maka dapat disimpulkan bahwa tidak terdapat perbedaan asupan lemak responden dengan kejadian DM. Hasil penelitian ini didukung oleh Nagao et al. yang menyatakan bahwa tidak ada hubungan antara asupan lemak dengan kejadian DM [12]. Penelitian yang dilakukan Wanders et al. juga menyatakan bahwa lemak tidak mempengaruhi kejadian DM [13]. Hal tersebut dikarenakan tidak semua jenis lemak dapat memicu terjadinya DM, tergantung jenis dan sumber bahan makanan yang dikonsumsi. Konsumsi bahan makanan sumber MUFA (Monounsaturated Fatty Acid) dan PUFA (Polyunsaturated Fatty Acid) memiliki manfaat dalam mengurangi resiko resistensi insulin dan berperan untuk kontrol glikemik dalam tubuh [14].

Tabel 3 menunjukkan bahwa asupan kolesterol dengan kategori normal pada responden DM sebanyak 16 orang sedangkan responden Non DM sebanyak 12 orang. Asupan kolesterol dengan kategori berlebih pada responden DM sebanyak 4 orang sedangkan responden Non DM sebanyak 3 orang. Konsumsi kolesterol yang tinggi dapat menyebabkan terjadinya dislipidemia yang merupakan faktor resiko terjadinya DM [15]. Beberapa pendapat lainnya menyatakan kolesterol dapat memicu stress jaringan salah satunya pada pancreas yang memiliki peran dalam produksi insulin [16]. Namun berdasarkan uji statistik nilai p adalah 1 maka dapat disimpulkan bahwa tidak terdapat perbedaan asupan kolesterol dengan kejadian DM. Hasil ini sama dengan penelitian yang dilakukan Baghdasarian et al. yang menyatakan bahwa tidak ada perbedaan yang signifikan antara asupan kolesterol $<200,200-<300$ dan $\geq 300 \mathrm{mg}$ per hari dengan kejadian Diabetes Mellitus [17]. Dari hasil analisis epidemiologi tidak didapatkan hubungan konsumsi kolesterol dengan kejadian DM begitu juga dari penelitian klinis yang belum menunjukkan pengaruh langsung 
kolesterol terhadap metabolisme glukosa pada penderita diabetes [18]. Hasil penelitian menunjukkan tidak adanya perbedaan yang signifikan juga dikarenakan asupan kolesterol penderita DM dan Non DM yang hampir sama.

Tabel 3 menunjukkan bahwa asupan SFA dengan kategori normal pada responden DM sebanyak 2 orang sedangkan responden Non DM sebanyak 1 orang. Asupan SFA dengan kategori berlebih pada responden DM sebanyak 18 orang sedangkan responden Non DM sebanyak 14 orang. Peningkatan serum SFA dalam tubuh berkaitan dengan resistensi insulin, peningkatan konsentrasi serum glukosa dan inflamasi jaringan [19]. Salah satu jenis SFA yaitu asam palmitat dapat mengaktivasi sitokin inflamasi dan dapat menyebabkan lipotoksisitas pada sel beta pankreas [20]. Hasil penelitian tidak sejalan dengan pernyataan tersebut dimana hasil uji statistik nilai $\mathrm{p}$ adalah 1 maka dapat disimpulkan bahwa tidak terdapat perbedaan asupan SFA dengan kejadian DM. Penelitian yang dilakukan Liu et al. menyatakan tidak ada hubungan antara asupan SFA dengan Diabetes Mellitus [21]. Hasil penelitian lain yang dilakukan oleh Souza et al. juga menyatakan tidak ada hubungan antara asupan SFA dengan kejadian DM [22]. Penelitian case-cohort dengan skala besar mendapatkan hasil bahwa beberapa jenis SFA seperti asam palmitat, asam stearate, dan asam miristat secara positif berhubungan dengan kejadian DM, berbeda dengan jenis SFA lainnya yaitu asam pentadekanoat dan asam heptadekanoat yang tidak berhubungan dengan kejadian DM [23], sehingga tergantung jenis SFA yang dikonsumsi.

\section{d. Asupan Karbohidrat dengan Kejadian DM}

Data asupan karbohidrat responden diperoleh dari hasil SQ-FFQ. Berikut adalah hasil analisis hubungan asupan karbohidrat dengan kejadian DM melalui uji Chi Square pada SPSS.

Tabel 4. Hubungan Asupan Karbohidrat dengan Kejadian DM

\begin{tabular}{ccccc}
\hline Kategori & \multicolumn{2}{c}{ Kejadian DM } & \multirow{2}{*}{ Jumlah } & $\boldsymbol{P}$ Value \\
\cline { 2 - 5 } asupan & Non DM & DM & & \\
\hline Baik & 11 & 9 & 20 & \\
Lebih & 4 & 11 & 15 & 0,167 \\
Total & 15 & 20 & 35 & \\
\hline
\end{tabular}

Tabel 4 menunjukkan bahwa asupan karbohidrat dengan kategori baik pada responden DM sebanyak 9 orang sedangkan responden Non DM sebanyak 11 orang. Asupan karbohidrat dengan kategori lebih pada responden DM sebanyak 11 orang sedangkan responden Non DM sebanyak 4 orang. Berdasarkan uji statistik nilai $\mathrm{p}$ adalah 0,167 maka dapat disimpulkan bahwa tidak terdapat perbedaan asupan karbohidrat dengan kejadian DM. Hasil tersebut sesuai dengan penelitian yang menunjukkan tidak ditemukan adanya perbedaan antara asupan karbohidrat dan risiko diabetes. Hubungan antara asupan karbohidrat dengan DM tidak konsisten [24]. Penelitian menunjukkan pola makan tinggi karbohidrat tidak menyebabkan kerusakan pada kontrol glikemik. Selain itu, pola makan tinggi karbohidrat memiliki dampak yang sama dengan pola makan rendah karbohidrat jika terdiri dari bahan makanan berserat tinggi dan indeks glikemik rendah [25]. 


\section{e. Asupan Serat dengan Kejadian DM}

Data asupan serat responden diperoleh dari hasil SQ-FFQ. Berikut adalah hasil analisis hubungan asupan serat dengan kejadian DM melalui uji Chi Square pada SPSS.

Tabel 5. Hubungan Asupan Serat dengan Kejadian DM

\begin{tabular}{ccccc}
\hline Kategori & \multicolumn{2}{c}{ Kejadian DM } & Jumlah & $\boldsymbol{P}$ Value \\
\cline { 2 - 5 } asupan & Non DM & DM & & \\
\hline Defisit & 15 & 18 & 33 & \\
Baik & 0 & 2 & 2 & 0,496 \\
Total & 15 & 20 & 35 & \\
\hline
\end{tabular}

Tabel 5 menunjukkan bahwa asupan serat dengan kategori defisit pada responden DM sebanyak 18 orang sedangkan responden Non DM sebanyak 15 orang. Asupan serat dengan kategori baik pada responden DM sebanyak 2 orang sedangkan pada responden Non DM sebanyak 0 orang. Berdasarkan uji statistik nilai $\mathrm{p}$ adalah 0,496 maka dapat disimpulkan bahwa tidak terdapat perbedaan asupan serat dengan kejadian DM. Hasil ini disebabkan karena $100 \%$ responden non DM dan $90 \%$ responden DM memiliki asupan serat yang tergolong defisit. Hal ini sesuai dengan penelitian di Rumah Pelayanan Lansia Pucang Gading Semarang yang menunjukkan tidak adanya hubungan yang bermakna antara asupan serat dengan kadar glukosa darah dan kejadian DM [26]. Penelitian lain di Depok menunjukkan hasil yang serupa, yaitu tidak adanya hubungan yang bermakna antara asupan serat dengan kadar gula darah puasa dan kejadian DM [27].

\section{f. Status Gizi dengan Kejadian DM}

Data status gizi responden diperoleh melalui pengukuran antropometri berat badan dan tinggi badan untuk menentukan indeks massa tubuh (IMT). Berikut adalah tabel silang dan analisis hubungan antara status gizi dengan kejadian DM melalui uji Chi Square pada SPSS.

Tabel 8. Perbedaan Status Gizi dengan Kejadian DM.

\begin{tabular}{|c|c|c|c|c|}
\hline \multirow{2}{*}{ Kategori } & \multicolumn{2}{|c|}{ Kejadian DM } & \multirow{2}{*}{ Jumlah } & \multirow{2}{*}{$P$ Value } \\
\hline & Non DM & DM & & \\
\hline $\begin{array}{c}\text { Underweight dan } \\
\text { Normal }\end{array}$ & 6 & 2 & 8 & \\
\hline $\begin{array}{l}\text { Overweight dan } \\
\text { Obesitas }\end{array}$ & 9 & 18 & 27 & 0,051 \\
\hline Total & 15 & 20 & 35 & \\
\hline
\end{tabular}

Tabel 8 menunjukkan bahwa status gizi underweight dan normal pada responden Non DM sebanyak 6 orang dan 2 orang pada responden DM. Responden Non DM yang memiliki status gizi overweight dan obesitas sejumlah 9 orang sedangkan responden DM sejumlah 18 orang. Dari hasil uji Chi-Square didapatkan 
tidak ada perbedaan antara status gizi dengan kejadian DM pada pasien lansia $(p=0,051)$. Hal ini disebabkan oleh banyaknya proporsi responden non DM yang overweight dan obesitas, yaitu sebesar $64 \%$. Hasil penelitian ini sejalan dengan penelitian pada Lansia di Puskesmas Pasar Ikan Bengkulu yang menunjukkan tidak adanya hubungan antara status gizi dengan kejadian DM [28]. Penelitian lain pada lansia di Provinsi Kalimantan Barat juga menunjukkan tidak adanya hubungan antara status gizi dengan kejadian DM [29].

Pada penelitian ini, P-value yang didapatkan adalah 0,051 yaitu borderline antara ada perbedaan dan tidak. Walaupun termasuk dalam kategori tidak ada perbedaan, nilai tersebut memiliki nilai yang sangat mendekati kategori terdapat perbedaan. Kondisi ini dapat disebabkan karena jumlah sampel yang hanya sebesar 35 orang. Bila jumlah sampel lebih banyak, kemungkinan besar hasil yang didapatkan akan siginifikan. Adanya perbedaan yang siginifikan antara status gizi DM dan non-DM disebabkan karena pada individu yang mengalami obesitas, asupan makanan meningkat akibat adanya resistensi insulin yang terjadi di otak yang menyebabkan fungsi insulin sebagai penekan nafsu makan berkurang, yang menyebabkan tingginya asupan energi [30].

\section{KESIMPULAN}

Asupan energi mempengaruhi kejadian DM pada pasien lansia rawat jalan RSUD Dr. Saiful Anwar. Sedangkan asupan lemak, karbohidrat, serat, kolesterol dan SFA tidak mempengaruhi kejadian DM. Tidak ada perbedaan yang signifikan antara status gizi pasien lansia dengan kejadian DM.

\section{DAFTAR PUSTAKA}

[1] WHO, "Diabetes," 2018. [Online]. Available: https://www.who.int/news-room/factsheets/detail/diabetes. [Accessed: 08-Mar-2019].

[2] WHO, "Global Report on Diabetes," 2016. Geneva, World Health Organization

[3] Kemenkes RI, "Hasil Utama Riset Kesehatan Dasar Nasional Tahun 2018," Jakarta, 2018.

[4] A. Bigelow and B. Freeland, "Type 2 Diabetes Care in the Elderly," J. Nurse Pract., vol. 13, no. 3, pp. 181-186, 2017.

[5] Y. Wu, Y. Ding, Y. Tanaka, and W. Zhang, "Risk Factors Contributing to Type 2 Diabetes and Recent Advances in the Treatment and Prevention," Int. J. Med. Sci., vol. 11, no. 11, pp. 1185-1200, 2014.

[6] E. Wilmot and I. Idris, "Early onset type 2 diabetes: Risk factors, clinical impact and management," Ther. Adv. Chronic Dis., vol. 5, no. 6, pp. 234-244, 2014.

[7] M. Hu et al., "Prevalence, Awareness and Associated Risk Factors of Diabetes among Adults in Xi'an, China," Sci. Rep., vol. 7, no. 1, pp. 1-9, 2017.

[8] V. Bellou, L. Belbasis, I. Tzoulaki, and E. Evangelou, "Risk factors for type 2 diabetes mellitus: An exposure-wide umbrella review of meta-analyses," PLoS One, vol. 13, no. 3, pp. 1-27, 2018.

[9] G. Kusnadi, E. Murbawani, and D. Fitranti, "FAKTOR RISIKO DIABETES MELITUS PADA PETANI DAN BURUH," J. Nutr. Coll., vol. 6, no. 2, pp. 138-148, 2017. 
[10] R. Fitri and Y. Wirawanni, "Asupan Energi, Karbohidrat, Serat, Beban Glikemik, Latihan Jasmani dan Kadar Gula Darah pada Pasien Diabetes Mellitus Tipe 2," Media Med. Indones., vol. 46, no. 14, pp. 121-131, 2012.

[11] S. H. Ley, O. Hamdy, V. Mohan, and F. B. Hu, "Series Diabetes 1 Prevention and management of type 2 diabetes: dietary components and nutritional strategies," Lancet, vol. 383, no. 9933, pp. 1999-2007, 2014.

[12] M. Nagao, A. Asai, H. Sugihara, and S. Oikawa, "Fat intake and the development of type 2 diabetes," Endocr. J., vol. 62, no. 7, pp. 561-572, 2015.

[13] A. J. Wanders et al., "Fatty acid intake and its dietary sources in relation with markers of type 2 diabetes risk: The NEO study," Eur. J. Clin. Nutr., vol. 71, no. 2, pp. 245-251, 2017.

[14] F. Qian, A. A. Korat, V. Malik, and F. B. Hu, "Metabolic Effects of Monounsaturated Fatty Acid - Enriched Diets Compared With Carbohydrate or Polyunsaturated Fatty Acid - Enriched Diets in Patients With Type 2 Diabetes: A Systematic Review and Meta-analysis of Randomized Controlled Trials," Diabetes Care, vol. 39, no. August, pp. 1448-1457, 2016.

[15] J. D. Schofield, Y. Liu, and P. R. Rayaz, "Diabetes Dyslipidemia," Diabetes Ther., vol. 7, no. 2, pp. 203-219, 2016.

[16] J. A. Paniagua, "Nutrition, insulin resistance and dysfunctional adipose tissue determine the different components of metabolic syndrome," World J. Diabetes, vol. 7, no. 19, pp. 483-514, 2016.

[17] S. Baghdasarian et al., "Dietary Cholesterol Intake Is Not Associated with Risk of Type 2 Diabetes in the Framingham Offspring Study," Nutrients, vol. 10, no. 665, pp. 1-9, 2018.

[18] M. L. Fernandez and C. J. Andersen, "Effects of dietary cholesterol in diabetes and cardiovascular disease," Clin. Lipidol., vol. 9, no. 6, pp. 607-616, 2014.

[19] M. Guasch-ferr et al., "Total and subtypes of dietary fat intake and risk of type 2 diabetes mellitus in the Prevención con Dieta Mediterránea (PREDIMED) study," Am. J. Clin. Nutr., vol. 105, no. August, pp. 723-735, 2017.

[20] R. B. Sharma and L. C. Alonso, "Lipotoxicity in the Pancreatic Beta Cell : Not Just Survival and Function, but Proliferation as Well?," Curr Diab Rep, vol. 14, no. 492, pp. 1-9, 2014.

[21] S. Liu, Y. T. Van Der Schouw, S. S. Soedamah, and A. M. W. Spijkerman, "Intake of dietary saturated fatty acids and risk of type 2 diabetes in the European Prospective Investigation into Cancer and Nutrition- Netherlands cohort: associations by types, sources of fatty acids and substitution by macronutrients," Eur. J. Nutr., vol. 0, no. 0, p. 0, 2018.

[22] R. J. De Souza et al., "Intake of saturated and trans unsaturated fatty acids and risk of all cause mortality, cardiovascular disease, and type 2 diabetes: systematic review and meta-analysis of observational studies," BMJ, vol. 351, no. h3978, pp. $1-16,2015$.

[23] N. G. Forouhi et al., "Differences in the prospective association between individual plasma phospholipid saturated fatty acids and incident type 2 diabetes: the EPICInterAct case-cohort study," Lancet Diabetes Endocrinol, vol. 2, no. October, pp. 810-818, 2014.

[24] W. Sami, T. Ansari, N. S. Butt, M. Rashid, and A. Hamid, "Effect of diet on type 2 
diabetes mellitus : A review," Int. J. Health Sci. (Qassim)., vol. 11, no. 2, pp. 65$71,2017$.

[25] C. Jung and K. M. Choi, "Impact of High-Carbohydrate Diet on Metabolic Parameters in Patients with Type 2 Diabetes," Nutrients, vol. 9, no. 322, pp. 1-21, 2017.

[26] R. Yuniati, S. F. Pradigdo, and M. Z. Rahfiludin, "Hubungan Konsumsi Karbohidrat, Lemak, dan Serat dengan Kadar Glukosa Darah pada Lanjut Usia Wanita," J. Kesehat. Masy., vol. 5, no. 4, pp. 759-767, 2017.

[27] A. . Werdani and Triyanti, "Asupan Karbohidrat sebagai Faktor Dominan yang Berhubungan dengan Kadar Gula Darah Puasa," J. Kesehat. Masy., vol. 9, no. 1, pp. 71-77, 2014.

[28] M. Audina, T. C. Maigoda, and T. Wahyu, "Status Gizi, Aktivitas Fisik dan Asupan Serat Berhubungan dengan Kadar Gula Darah Puasa Penderita DM Tipe 2," J. IImu dan Teknol. Kesehat., vol. 6, no. 1, pp. 59-71, 2018.

[29] W. Dianah, M. E. Yudhya, and B. Herwanti, "HUBUNGAN STATUS GIZI DAN AKTIVITAS FISIK TERHADAP DIABETES MELLITUS PADA LANSIA DI PROVINSI KALIMANTAN BARAT (ANALISIS DATA RISKESDAS 2007)," Nutr. Diaita, vol. 8, no. 1, pp. 33-40, 2016.

[30] PERKENI, Konsensus Pengelolaan dan Pencegahan Diabetes Mellitus Tipe 2 di Indonesia. Pengurus Besar Perkumpulan Endokrinologi Indonesia, 2015. 